\title{
Upaya Menemukan Kesimbangan Hubungan Pusat Dan Daerah
}

\author{
Sudi Fahmi
}

\begin{abstract}
It is obvious, that the Decentralization that occurred through Law No. 22/1999 granted the political decentralization. However, the substance of Law No. 32/2004 is administrative decentralization. It is suspected that through Law No.23/2004 re-centralization in local govemance has occurred.
\end{abstract}

\section{Pendahuluan}

Dari awal pengesahan Undang-Undang No.22 Tahun 1999 tentang Pemerintahan Daerah, sudah banyak nada pesimis yang dilontarkan sebagian masyarakat bahwa undangundang ini tidak akan mampu bertahan dalam waktu yang cukup lama, karena Pemerintah Pusat tidak ikhlas untuk menyerahkan sebagian besar "kewenangannya" kepada daerah. Namun hal ini harus dilakukan karena kuatnya desakan untuk mengganti pola hubungan pusat dan daerah yang highly centralized menjadi hubungan yang lebih terdesentralisasi.

Barangkali tidak ada aspek pemerintahan di Indonesia yang lebih sering mengalami perubahan, baik pada semangat maupun regulasinya, selain otonomi daerah dan desentralisasi pemerintahan. Barangkalijuga, tidak ada persoalan pemerintahan di Indonesia yang implementasinya memilikj intensitas kesulitan setinggi desentralisasi politik di Indonesia. lbarat buah simalakama bagi rakyat, begitulah desentralisasi di indonesia. Dengan kekuasaan terpusat di Jakarta, pemerintah daerah dan rakyat di daerah tidak punya ruang gerak karena semua serba ditentukan dari atas. Dengan kekuasaan yang disebarkan secara cepat pada daerah-daerah, pemerintah daerah kebanjiran kekuasaan namun tetap saja rakyat daerah tidak mempunyai keleluasaan berarti.' Karena kekuasaan itu hanya dinikmati oleh

\footnotetext{
1 Pembentukan Daerah Otonom secara simultan merupakan kelahiran status oloromi yang didasarkan atas aspirasi dan kondisi obyektif dari masyarakat yang berada di wilayah tertentu. Aspirasi tersebut terwujud dengan diselenggarakannya desentralisasi. Desentralisasi di sebut pula otoromisasi, karena otonomi óiberikan kepada masyarakat dan bukan daerah atau Pemerintah Daerah, lihat Bhenyamin Hoessein, Pembagian Kewenangan Antara Pusat Dan Daerah, Makalah, Pusat Pengembangan Otonoml Daerah Fakultas Hukum Unibraw, Malang, 2001, hlm. 4.
} 
segelintir 'elit penguasa' daerah.

Wacana revisi Undang-Undang (UU) Nomor 22 Tahun 1999 tentang Pemerintahan Daerah diwarnai penolakan sebagian besar BupatiWali Kota, Partai Golkar, juga tim Ryaas Rasyid yang dulu membuatnya. Kelompok yang kontra berpendirian bahwa belum waktunya melakukan revisi. Alasan yang dikemukakan, belum ada penelitian yang validitasnya dapat dipertanggungjawabkan untuk menyatakan bahwa UU No. 22 Tahun 1999 menimbulkan masalah dalam penyelenggaraan pemerintahan daerah. Bahkan menurut mereka, kesalahan justru dilakukan oleh pemerintah pusat karena lamban membuat peraturan perundangundangan yang lebih rendah untuk melaksanakan UU No. 22 Tahun 1999. Sementara itu, kelompok pendukung revisi melihat bahwa sudah cukup kuat alasan untuk melakukan revisi karena dalam praktek UU No.22 Tahun 1999 cenderung menimbulkan masalah dalam perkembangan pemerintahan daerah. Alasan yang sering dikemukakan adalah pelaksanaan otonomi daerah sudah kebablasan sehingga menimbulkan masalah dalam pelaksanaan pemerintahan daerah. Contohnya, keengganan Bupati/Wali Kota untuk memenuhi undangan rapat Gubernur karena merasa tidak ada hubungan hierarki antara pemerintah provinsi dengan pemerintah Kabupaten/Kota. ${ }^{2}$

Pilihan kebijakan desentralisasi sebagaimana dituangkan dalam UU Nomor 22 Tahun 1999 dan UU Nomor 25 Tahun 1999 bukan merupakan sebuah pilihan final. Pilihan kebijakan desentralisasi adalah pilihan kebijakan jangka pendek untuk penyelamatan diri. Bahkan, bagi kepentingan negara-bangsa yang bernama Indonesia sekalipun, pilihan desentralisasi adalah pilihan yang diambil untuk menyelamatkan keutuhannya, persatuannya, NKRI - nya. ${ }^{3}$

Seringkali desentralisasi cenderung merupakan pilihan yang harus diambil Pemerintah Pusat, ketika yang disebut terakhir

\footnotetext{
${ }^{2}$ Jimly Asshidiqie. Konslitusi \& Konslitusionalisme Indonesia. Kerjasama Mahkamah Konstitusi Republik Indonesia dan Pusat Studi HTN Fakultas Hukum Universitas Indonesia. Jakarta. 2004. him.213. Dalam rumusan Pasal 18 ayat (1) yang baru (hasil perubahan kedua tahun 2000), ditegaskan: "Negara Republik Indonesia dibagi atas daerah-daerah provinsi, kabupaten dan kota itumempunyai pemerintah daerah yang diatur dengan undang-undang". Dengan adanya perkataan "dibagi atas" maka berarti hubungan antara Pusat dan Provinsi, serta antara Provinsi dan Kabupaten/Kota bersifat hirarkis-vertikal. Dengan demikian, siłat non-hirarkis yang terkandung dalam Undang-Undang No.22 Tahun 1999 telah dikoreksi oleh Perubahan UUD 1945 pada tahun 2000 melalui perbaikan UUD 1945 pada rumusan Pasal 18 ayat (1) tersebut.

${ }^{3}$ Lihat Praktino, Desentraliasi Pilihan Yang Tidak Pernah Final, dalam Jim Schiller (edt). Jalan Terjal Reformasi Lokal, (Program Pascasarjana Politik Lokal dan Otonomi Daerah. UGM, Yogyakarta, 2003). Dalam pemyataannya desentralisasi merupakan antitesa dari sentralisas I penyelenggaraan pemerintahan. Antara dua kutub itu dalam perkembangannya tidakjarang diletakkan pada kutub yang berlawanan, kelompokin ldipelopori oleh David Slater, lihat Sodjuangon Situmurang, Model Pembagian Urusan Pemerintahan Antara Pemenintah, Provinsi dan Kabupaten/Kota, Disertasi, Pascasarjana UI, Jakarta, 2002, hlm.21, padahal dl dalam negara kesatuan di samping kelisu untuk mempertentangkan keduanya juga diantara keduanya tidak bisa ditladakan sama sekali. Artinya kedua korsep, sistem bahikan teori dimaksud saling melengkapi dan membutuhkan dalam kerangka yang ideal sebagai sendi negara demokratis. Kelompok ini dipeloporioleh Cheema dan Rondeinelli.
} 
ini mulai kehilangan kendali dan dukungan daerah. Dengan demikian, bisa jadi kebljakan desentralisasi tersebut direvisi bila Pemerintah Pusat kembali memperoleh sumber legitimasinya, terutama jika pelaksanaan Otonomi Daerah tidak membawa perubahan yang lebih baik pada masyarakat. Oleh karena itu, pilihan kebjjakan desentralisasi sebagaimana dituangkan dalam Undang-Undang Nomor 22 Tahun 1999 dan Undang-Undang Nomor 25 Tahun 1999 boleh jadi bukan menupakan sebuah pilihan final. Untuk menjadikannya final, diperlukan sebuah komitmen untuk menjadikan desentralisasi itu sebagai referensi utama dalam penataan hubungan pusat dan daerah.

Perubahan besar telah terjadi dalam pelaksanaan Pemerintahan Daerah ketika DPR telah mengesahkan 2 (dua) RUU tentang Pemerintahan Daerah dan Perimbangan Keuangan antara Pusat dan Daerah yang menggantikan Undang-Undang Nomor 22 Tahun 1999 dan Undang-Undang Nomor 25 Tahun 1999. Undang-undang No. 32 Tahun 2004 menggantikan UU No. 22
Tahun 1999 dan UU No. 25 Tahun 1999 menggantikan UU No. 25 Tahun 1999.

UU No. 32 Tahun 2004 sebenarnya bukanlah merevisi tapi mengganti UndangUndang Nomor 22 Tahun 1999. Bukan semata-mata karena fisik Undang-Undang Nomor 32 Tahun 2004 yang memiliki 16 bab dengan 240 pasal sangat berbeda jauh dibanding Undang-Undang Nomor 22 Tahun 1999 yang hanya dengan 16 bab dan 134 pasal. Tetapi dari sistematika dan nomenklaturnya, ada perbedaan sangat prinsip atau mendasar diantara keduanya. Perbedaan yang mendasar dari kedua Undang-Undang tersebut baik mengenai subtansi desentralisasi, Otonomi Daerah hingga pemaknaan pemerintahan daerah, Pemerintah Daerah dan lainnya. Dilihat dari desentralisasi yang dilaksanakan, UndangUndang Nomor 22 Tahun* 1999 jelas memberikan desentralisasi politik namun di dalam Undang-Undang Nomor 32 Tahun 2004 yang terjadi adalah desentralisasi administrasi. 4

\footnotetext{
'Dengan demidjan Pemerintah Indonesia tidakhanya menganut desentralisasi teritorial atau desentralisasi politik, totapidesentralisasiadministrasi yarg disebut sebagai dekonsentrasi. Pelaksanaan desenlarisasidan otonomi tidak dapat dilihat semala-mata sebagai suatu proses teknik, melainkan sebagai proses interaksi yang dinamik dari berbagaifaktor, yang sering sultit untuk diperhinungkan terlebih dahulu. Sult dipemitungkan terleih dahulu, dan inilah yang sering disebut sebagaj proses interaksi politik Berbagallaklor baik politik, sosial, ekonomi, organisasi, maupun tingkah laku aken mempengaruhi pelaksanaan desentralisasi dan otonomi. Lebih jauh tentang hal ini dapat dibaca, Gabriel U. Iglesias. Implementation, The Problem of Achieving Results, Eropa, Manila, 1976, hlm 35 dst. Bandungkan dengan G.Shabbir Cheema and Dennis A. Rondinelli, Implementation Decentralizatton Proggrammes in Asia, Locall Capacity of Rural Development, UNRCD, Nagoya, 1983, hlm. 17-27.Menurut Leemans, AF. Dalam Changing Pattems of Local Govemment. The Hague, IULA, 1970. Membedakan adanya dua tipe desentralisasi yaitu Pemerintah Daerah (local govemment) dan pemerintah wilayah (field administration). Cara pandang administratif jelas mengedepankan persepsi pusat, sedangkan yang demokratikmenooba untukmelihat kekuatan lokal sebagai positive resources untukpencapaian tujuan-tuguan bersama. Namun menurut Paul D. Hutchrot, yang ideal menuntnya adalah bagaimana mencari keseimbangan antara kedua perspektif tersebut dengan melihat desentralisasi politik dan desentralisasiadministratif secara integraltidak parsial unluk sebesar-besamya kepentingan pubfik dalam "Centralization and Decentralization in Administration and Politics: Assessing Territorial Dimensions of Authority and Power, in Govemment", Intemational Joumal of Policy and Administration, Vol. 14, No. 1, Januari 2001.
} 
Sudi Fahmi. Upaya Menemukan Kesimbangan Hubungan...

Permasalahan yang dapat dimunculkan dalam tulisan ini, sistem desentralisasi dan otonomi daerah yang bagaimanakah yang sesuai dengan kebutuhan bangsa Indonesia, supaya terjadi keseimbangan hubungan antara Pusai dan Daerah?

\section{Bayang-bayang Resentralisasi}

Sebagian kalangan masyarakat menilai aura dalam Undang-Undang Nomor 32 Tahun 2004 ini telah tejangkiti sindrome resentralisasi. Semangat resentralisasi yang membayangi pelaksanaan otonomi daerah ini jelas tampak dengan pemaknaan desentralisasi dan otonomi daerah sebagai: penyerahan wewenang pemerintahan oleh Pemerintah kepada Daerah Otonom untuk mengatur dan mengurus urusan pemerintahan dalam sistem NKRI. Sedang otonomi daerah dirumuskan maknanya sebagai hak, wewenang dan kewajiban daerah otonom untuk mengatur dan mengurus urusan pemerintahan dan kepentingan masyarakat setempat sesuai dengan peraturan perundang. undangan.

Ada "bahaya besar' bagi masyarakat dan daerah dengan. perubahan undang-undang ini yang tidak diperhatikan banyak pihak. Karena masyarakat terlebih bagi orang daerah sangat terbuai dengan 'kenyataan baru' bila dalam masa depan akan dilangsungkan pemilihan kepala daerah, baik Gubernur, BupatiWalikota secara langsung, sebagaimana mereka memilih Presiden beberapa waktulalu. Harapannya, akan muncul Gubernur/Bupati/Walikota yang memang merupakan orang populer, orang yang mereka idolakan sebagai pemimpin. Benarkah dan bagaimana dampaknya bagi kehidupan demokrasi di daerah ?

Sebenarnya pilkada langsung ini bisa dikatakan sekedar sebagai 'permainan baru'. Pasainya, dengan dilaksanakannya pilkadal seakan dibuka ruang demokrasi di tingkat lokal. Tetapi ruang kewenangan bagi yang terpilih itu nanti berkurang. Akhirnya siapapun yang terpilih dalam pilkada itu akan tetap menjadi mainan baru bagi pusat. Sebab ia tetap dikendalikan pusat,". Permainan baru' itu misalnya seperti dalam supervisi APBD, pusat tetap dapat mengontrol. Dalam pengambilan kebijakan publik yang lain di daerah yang mestinya diputuskan dengan persetujuan DPRD (sebagai pembuat check and balances) juga akan sulit dilaksanakan. Mengingat kewenangan DPRD bisa dikatakan sudah 'dikebiri' dengan hadimya PP Nomor 25 Tahun 2004 tentang 'Pedoman Penyusunan Tata Tertib DPRD'. Karena peraturan pemerintah ini membuat DPRD tidak lagi memiliki kebebasannya sebab selalu harus berkonsultasi dengan pusat.

Pelaksanaan pilkada langsung, hakikatnya merupakan konsekuensi logis dari pelaksanaan pemilihan presiden langsung beberapa waktu lalu. Dengan logika, jika Presiden dipilih langsung, mengapa Gubernur dan Bupatif Walikota harus dipilih oleh penwakilan rakyat. Karena dengan pemilthan langsung, rakyat akan bisa memilih sesuai hati nuraninya. Sekalipun alasan normatif bisa dicari dalam arah policy reform (amandemen konstitusi) yang menuju sistem pemilihan kepala daerah secara langsung. Namun di balik itu sebenarnya ada persoalan politis yang mendasarinya.

Hal itu diakui pula oleh M. Ryaas Rasyid, ${ }^{5}$ bahwa sebenarnya kalau mau jujur, satu-

${ }^{5}$ Makalah dalam Seminar Nasional Pilkada 2005, Terobosan Otonomi atau Kekalutan Konsep, Keluarga Mahasiswa Administrasi Negara Universitas Gadjah Mada, 19 Maret 2005. 
satunya rujukan dan sekaligus pengalaman rakyat Indonesia dalam pemilihan langsung (dengan metodologi pemilihan yang universal demokratis) adalah pemilihan presiden 2004. Pilkada secara sederhana bisa diasumsikan sama dengan Pemilihan Presiden dalam skala yang lebih kecil. Persepsi orang banyak pun tidak akan jauh melenceng dari situ. Tetapi, dengan tihainya, pembuat UU merumuskan aturan khusus yang membedakan Pilkada dan Pilpres.

Sekalipun demikian, jangan pernah berpikir bila pilkada langsung itu akan sereformis yang dibayangkan orang. Pada tahap paling awal proses pemithan dimana pengusulan nama calon hanya bisa dilakukan partai politik atau gabungan partai politik yang memperoleh sekurang-kurangnya $15 \%$ jumlah kursi DPRD atau $15 \%$ akumulasi perolehan suara sah dalam pemilu DPRD di daerah bersangkutan seperti tertuang dalam pasal 59 (2) berarti sudah menutup calon independen (independent candidate) yang tidak diusulkan parpol sekalipun didukung masyarakat pemilih.

Dengan kata lain, partai memang tidak lagi memilih melalui wakilnya di legislatif, apakah ada jaminan pilkada langsung akan dilaksanakan dengan jurdil? Dari undangundang yang ada tersebut, prakondisi apa yang dapat lebih menjamin bila pilkadal berlangsung secara demokratis? Pasca putusan Mahkamah Konstitusi, Departemen
Dalam Negeri (Depdagri) masih belum bisa memutuskan kemana KPUD harus mempertanggungjawabkan pelaksanaan Pilkada langsung. ${ }^{6}$ Direktur Jenderal Otonomi Daerah Depdagri Progo Nurdjaman mengatakan, KPUD yang memakai anggaran APBD dalam Pilkada langsung harus bertanggungjawab kepada Pemerintah Daerah. Dalam kesempatan yang sama, KPUD bertanggungjawab kepada publik, agar dapat menilai independensi KPUD dalam pelaksanaan Pilkadal."

Slapa yang akan mengawasi KPUDDPRD? Ada banyak harapan yang telah membuai masyarakat dengan dilaksanakannya pilkada langsung tersebut. Pemilihan secara demokratis pastilah menjadi harapan. Tetapi apa arti dari semua itu jika kepala daerah yang temilih tidak lagi memiliki kewenangan yang cukup untuk menghasilkan keputusan dan kebijakan politik. Semua akan sangat terbatas ketika kewenangan daerah sudah menjadi sedemikian kecil.

Kehadiran Undang-Undang Nomor 32 Tahun 2004 telah memutarbalikkan desa dengan pelbagai macam peraturan barunya. Contohnya, sekretaris desa (carik) menurut Undang-Undang Nomor 32 Tahun 2004 adalah diangkat dari Pegawai Negeri Sipil (PNS) yang memenuhi persyaratan. Sementara Badan Perwakilan Desa (BPD) yang beberapa waktu lalu dengan semangat tinggi pemilihannya dilakukan secara langsung oleh warga desa di masa mendatang

${ }^{6}$ Mahkamah Konstitusi telah memutuskan hak uji maleri UU No.32 Tahun 2004 bahwa, Komisi Pemilihan Umum Daerah tidak bertanggung jawab kepada Dewran Perwakilan Rakyat Daerah, begilu pula partai politik atau gabungan partai politik yang tidak memilki kursi di DPRD, tetapi memiliki 15 persen suara dari akumulasi perolehan suara sah dalam Pemilu, bisa mengajukan pasangan calon Kepala Daerah dan Wakil Kepala Daerah. Lihat Harian Kompas tanggal 23 Maret 2005. Permohonan yang dikabulkan Mahkamah Konstitusi meliputi, Pasal 57 ayat (1); Pasal 66 ayat (3) huruf e; Pasal 67 ayal (1) huruf e; Pasal 82 ayat (2) UU No. 32 Tahun 2004.

${ }^{7}$ bid. 
menurut undang-undang ini ditetapkan dengan cara musawarah.

Dengan dilaksanakan Undang-Undang Nomor 32 Tahun 2004 ini, di masa depan akan terjadi birokratisasi desa yang sangat luar biasa. Sekalipun banyak ahli melihat dan mengakui jika pengaturan desa dalam Undang-Undang Nomor 22 Tahun 1999 banyak kelemahan, namun perubahan fundamental yang dilakukan melalui UndangUndang Nomor 32 Tahun 2004 yang justru mengarahkan terjadinya birokratisasi desa, hakikatnya adalah sebuah kemunduran yang disesalkan banyak pihak.

Persoalan yang terjadl ini belum mengingat ada 'komplikasi' lain yang harus dipikirkan juga dengan realitas politik sekarang ini. Dengan pemilihan presiden langsung beberapa waktu lalu, ada realitas kita memiliki presiden yang belum tentu sesuai dengan partai politik Gubernur/BupatiWalikota.

Apalagi kalau kemudian hal ini ditambah dengan adanya pilkada langsung. Dalam kondisi seperti sekarang ini belum tentu ada kesamaan visi misi Presiden dengan gubernur! bupati/ walikota yang berasal dari partai politik yang berbeda. Jadi, bagaimana Presiden akan melakukan koordinasi dan bagaimana pula koordinasi horizontal, ini akan menjadi persoalan dan kian meningkatkan kompleksitas persoalan pelaksanaan desentralisasi ini. Ini akan bisa menambah ketegangan pusat dan daerah dan juga akan sangat memungkinkan ada kebijakan pusat yang dilawan daerah.

Pemaknaan desentralisasi sebagai penyerahan kewenangan (UU No. 22 Tahun 1999) mengandung penghargaan terhadap daerah sebagai entitas politik yang sudah hidup sebelum Proklamasi Kemerdekaan. Sebaliknya pemaknaan desentralisasi sebagai penyerahan penanganan urusan pemerintahan, merupakan reduksi terhadap desentralisasi politik menjadi desentralisasi administratif. Konsekuensi dari diterapkannya desentralisasi administratit dalam proses desentralisasi yang hanya terjadi dalam tubuh birokrasi negara serta akan sangat ditentukan budi baik dan kemurahan hali pemerintah pusat.

Ada problem besar menghadang di depan, pelaksanana otonomi daerah berada dalam bayang-bayang resentralisasi yang ditutupi dengan euphoria pemilihan Kepala Daerah langsung, padahal euphoria ini menghadapi banyak permasalahan. Jika demikian, masyarakat dan kehidupan demokrasi yang akan terkena dampaknya.

\section{Makna Otonoml Daerah}

Kata "makna" yang dikaitkan (digabungkan) dengan kalimat" otonomi daerah menurut UUD $1945^{\circ}$ di sini ditafsirkan dari segi filosofi hukum dan hukum (segi dasar hukum). Dari segi filosofi hukum, kata "makna" di sini adalah makna yang tersirat, dalam arti makna yang tersembunyi di belakang kata "makna". Sedangkan dari segi hukum (dasar hukum), kata "makna" adalah makna yang tersurat, yaitu makna yang nyala tertulis.

Dari segi filosofi hukum, yang dimaksud "makna otonomi daerah menurut UUD $1945^{\text {" }}$ adalah makna yang tersirat atau yang tersembunyi di balik kalimat tersebut. Sedangkan dari segi hukum (dasar hukum), makna dari kalimat tersebut adalah makna yang tersurat atau yang ditetapkan secara eksplisit dalam peraturan hukum. Dengan demikian, hukum yang akan ditafsirkan sehingga dapal dipahami makna dari kalimat "makna otonomi daerah menurut UUD 1945" 
adalah Undang-Undang Dasar 1945 dan peraturan turunannya.

Otonomi adalah kebebasan dan kemandirian (vrijheid dan zelftandighoid) satuan pemesintahan lebih rendah untuk mengatur dan mengurus sebagian urusan pemerintahan. Urusan pemerintahan yang boleh diatur dan diurus secara bebas dan mandiri itu menjadi atau merupakan urusan rumah tangga satuan pemerintahan yang lebih rendah tersebut. Kebebasan dan kemandirian merupakan hakikat isi otonomi. ${ }^{\theta}$

Kebebasan dan kemandirian dalam otonomi sering menimbulkan salah pengertian bahkan kekuatiran. Otonomi dicurigai mengandung satu "cacat alami" yang senantiasa mengancam kesatuan. Salah pengertian ini dapat dipahami, baik karena kurangnya pemahaman maupun pengalamanpengalaman masa lalu dimana pernah terjadi peristiwa yang mengancam integrasi nasional.

Kebebasan dan kemandirian dalam otonomi bukan kemerdekaan (onathankeljjkheid, independency). Kebebasan dan kemandisian itu adalah kebebasan dan kemandirian dalam ikatan kesatuan yang lebih besar. Otonomi sekedar subsistem dari sistem kekuasaan yang lebih besar. 9
Dalam Hukum Tata Negara khususnya teori bentuk negara - otonomi adalah subsistem dari negara kesatuan (unitary state, eenheidsstaat). Otonomi adalah fenomena negara kesatuan. Segala pengertian (begrip) dan isi (materie) otonomi adalah pengertian dan isi negara kesatuan. Negara kesatuan merupakan landas batas dari pengertian dan isi otonomi. Berdasarkan landas batas tersebut dikembangkanlah berbagai aturan (rules) yang mengatur mekanisme yang akan menjelmakan keseimbangan antara tuntunan kesatuan dan tuntunan otonomi. Dan di sini letak kemungkinan; "spanning" yang timbul dari kondisi tarik menarik antara kedua kecenderungan tersebut.

Tarik menarik itu bukanlah sesuatu yang perlu dibilangkan. Upaya untuk menghilangkan tidak akan pernah berhasil karena merupakan sesuatu yang alami. Kehidupan bernegara atau berpemerintah tidak pernah terlepas dari kehidupan masyarakat, baik masyarakatnya sendiri maupun masyarakat di luarnya. Negara atau pemerintah yang baik adalah yang berkiprah sesuai dengan dinamika masyarakatnya. Dalam kondisj itulah semestinya dilihat kecenderungan kesatuan atau ke otonomi. ${ }^{10}$

Kalau segalanya dikembalikan pada kepentingan masyarakat dan terwujuơnya satu

\footnotetext{
${ }^{8}$ Bagir Manan, Perjalanan Historis Pasal 18 UUD 1945 (Perumusan dan Undang-Undang Pelaksanaannya). (UNSIKA, Karawang, 1992), hlm. 1.

- Baca lebih lanjut Ateng Syafrudin, Pasang Sunt Otonomi Daerah, Orasi Dies Natalis, (Unpar, Bandung, 1983), him. 18.

${ }^{10}$ Dari argumen teoritis dan kajian empirik, terlihat bahwa tidak ada suatu pola atau teori yang dapat djiadikan pedoman untukmenentukan strategi penyelenggaraan pemerintahan daerah. Pendulum dapat bergerak baik ke arah sentralisasi maupun desentralisasi. Pengalaman di negara-negara Afrika seperti Tanzania dan Sudan merupakan contoh bagaimana pendulum otonomi bergerak secara ekstrim yaitu dalam bentuk penghapusan daerah dan kemudian dihidupkan (revival) kembali. Baca Mawhood, P. (Ed.) Local Govemment in the This World, Chichester, John Wiley and Sons, 1983, hIm. 34. Teori pendulum ini terjadi juga di Indonesia apabila kita simak secara mendalam berbagai UU mengenai pemerintahan daerah, dimana lahimya undang-undang olonomi di indonesia sejak prokdamasi, selalumerupakan refleksi dari suasana politik pada masa dimana undang-
} 
pemerintahan yang sehat, tarik-menarik tersebut tidak boleh dilihat sebagai "spanning" di mana yang satu akan membahayakan yang lain, melainkan sebagai suatu bentuk dinamika yang alami yang akan senantiasa ada pada setiap tingkat perkembangan kehidupan bernegara alau berpemerintahan. Yang pokok adalah menciptakan mekanisme yang wajar agar setiap tarikan bukan saja berarti peringatan (warning) tetapi sekaligus sebagai masukan (feeding) bagi yang lain."

Tanpa pemahaman yang tepat, khususnya makna dan maksud otonomi sebagaimana diatur dalam UUD 1945, maka akan sulit untuk menentukan bagaimana seharusnya perkembangan otonomi di masa depan.12

Otonomi dapat diberi arti luas atau arti sempit. Dalam arti luas, otonomi mencakup pula tugas pembantuan (medebowind, coadministration). Baik otonomi maupun tugas pembantuan sama-sama mengandung kebebasan dan kemandirian. Perbedaan hanya pada tingkat kebebasan dan kemandirian. Pada otonomi, kebebasan dan kemandirian itu meliputi baik asas maupun cara menjalankannya. Sedangkan pada tugas pembantuan; kebebasan dan kemandirian hanya terbatas pada cara menjalankan. Karena sama-sama mengandung unsur otonomi, perbedaan hanya pada tingkat kebebasan dan kemandirian-maka tidak ada perbedaan mendasar antara otonomi dan tugas pembantuan. Tugas pembantuan adalah "broertjes van het zeltbeschikkingsrechf". ${ }^{13}$

undang otonomitersebut dillahirkan. Manakala partai politikyang berkuasa yang diwamei dengan kehendak yang kuat untuk berdemokrasi, maka pendulum otonomi akan mengarah ke desentralisasi. Sebaliknya manakala kekuasaan pindah ke sebuah elite penguasa, maka pendusum otonomi akan bergerak mendekatidekonsentrasi untuk dimanlaatkan elite penguasa tersebut menciptakan dukungan lokal kepadanya. Kondisi tersebutlah yang mewarnai perubahan-perubahan arah otonomi daerah di indonesia.

"Oleh karena itu wajar jlka di tingkat pemerintahan daerah pun belum terciptanya paradigma "check and balances". Proses untuk menuju ke arah itu nampaknya perlu dilakukan langkah-langkah yang konkrit dan sesegera mungkin untuk diartikulasi dan diagregasi di dalam UU bidang pemerintahan daerah yang baru. Dalam proses ke arah yang demikian tentu akan lebih lengkap bila didukung dengan kajian tentang prinsipprinsip demokrasi.

${ }^{2}$ Dengan beragamnya sistem otonomi yang terdapat dalam beberapa UU Pemerintah Daerah yang bersumber pada UUD 1945 yang asli, maka UUD 1945 pasca amandemen telah menunjukkan kemajuan yang sangal berarti dalam menghadapi perkembangan otonomi di masa yang dalang yaitu secara tegas merumuskan di dalam pasal 18 ayat (5) "Pemerintahan daerah menjalankan otonomi seluas-luasnya, kecuali urusan pemerintahan yang oleh Undang-Undang ditentukan sebagai urusan pemerintah pusal". Dengan diletakkannya mengenai sistem otonomi di dalam UUD 1945, secara yuridls memberikan landasan dan pedoman yang kuat bagi undang-undang organik di bidang pemerintahan daerah di masa datang.

${ }^{13}$ Burger, (et.al), Schets van nederlandse gemeenterecht, 3d druk, Semson, tahun 1983, hlm. 169. Baca pula C.W. Van Der Pot (et.ai)., Handboek Van Nederlandse Staalsrecht, 11ddruk, W.E.J. Tjeenk Willink-Zwolle, 1983, hilm. 526-527. la menyatakan "Vooral ten aanzien van provincie en gemeente wordt vanouds onderscheiden tussen twee vormen van decentralisatie, autonomie en medebewind (ook wel als zelibestuur aangeduid). Het water-schap kent vooral de autonomie, terwill blj de bedrijsorganisaties voor van medebewind sprak is". Desentralisasi teritorial berbentuk otonomi dan tugas pembantuan. Otonomi mengandung arti kemandirian atau mengatur dan mengurus urusan (rumah tangganya) sendiri. Sedangkan tugas pembantuan adalah tugas untuk 
Pandangan yang membedakan secara mendasar antara otonomi dan tugas pembantuan akibat pengaruh driekringenleer yang sudah lama ditinggalkan.

Demikian pula dengan Undang-undang Nomor 22 Tahun 1999, hendak membedakan secara tegas antara otonomi dan tugas pembantuan. Dalam Pasal 1 huruf $h$ ditegaskan bahwa:"Otonomi Daerah adalah kewenangan daerah otonom untuk mengatur dan mengurus kepentingan masyarakat setempat menurut prakarsa sendiri berdasarkan aspirasi masyarakat sesuai dengan peraturan perundang-undangan".

Sementara Pasal 1 huruf $g$ menetapkan bahwa:"Tugas pembantuan adalah penugasan dari Pemerintah kepada daerah dan/atau desa dan dari daerah propinsi ke daerah dan/atau desa untuk melaksanakan tugas tertentu yang disertai pembiayaan, sarana dan prasarana serta sumber daya manusia dengan kewajiban melaporkan pelaksanaannya dan pertanggungjawabannya kepada yang menugaskan."

Mengapa dalam tugas pembantuan periu ada penegasan mengenai "kewajiban mempertanggungjawabkan", sedangkan pada otonomi tidak? Apakah berarti otonomi tidak perlu dipertanggungjawabkan. Pertanggungjawaban otonomi nampak antara lain dalam pranata pengawasan (preventif, represif, dan umum). Dengan demikian dapat disimpulkan bahwa pembentuk undang-undang memang dengan sengaja dan bermaksud membedakan secara mendasar antara otonomi dan tugas pembantuan.

Pencantuman "kewajiban mempertanggungjawabkan", bermaksud menegaskan bahwa urusan pemerintahan dalam tugas pembantuan ada pada satuan pemerintahan yang dibantu. Pemerintah Daerah sekedar membantu, segala pertanggungjawaban tetap ada pada Pemerintah yang dibantu. Suatu jalan pikiran yang logis. ${ }^{14}$

Kembali pada persoalan otonomi dan tugas pembantuan perlu disadari kemanfaatan untuk tidak membedakan secara mendasar antara kedua pranata tersebut, dari pada terlanjur menekan-nekankan perbedaannya. Baik otonomi maupun tugas pembantuan adalah sarana untuk berotonomi.

Setelah menjajaki pengertian-pengertian otonomi, timbul pertanyaan: Dimana dan bagaimanakah otonomi tersebut menurut sistem UUD 1945? UUD 1945 adalah UndangUndang Dasar kilat, artinya disusun dalam waktu yang singkat antara 29 Mei - 18 Agustus 1945. ${ }^{15}$ Tetapi tidak berarti isinya sekedar kilatan pikiran penyusunan yang timbul pada saat itu. Berbagai ketentuannya merupakan perwujudan dari pikiran-pikiran atau konsepkonsep atau gagasan yang telah ada jauh sebelum tahun 1945. Misalnya konsep mengenai sistem otonomi telah digambarkan

membantu-apabila diperlukan-melaksanakan peraturan penundang-undangan yang lebih tinggi (undangundang dan peraturan pemerintah).

"Bagir Manan, Hubungan Antara Pusat dan Daerah Berdasarkan Asas Desentralisasi Menurut UUD 1945, Dlsertasi, (Universitas Padjajaran, Bandung, 1990), hlm. 132-133.

${ }^{15}$ Lihat Pidato Soekarno, tanggal 18 Agustus 1945 pada saat pengesahan UUD 1945, dalam Saafroedin Bahar dkk. (penyunting), Risalah Sidang BPUPKI-PPKI, (Sekretariat Negara RI., Jakarta, 1998), Cet. Kedua, Edisiv, him. 544. 
oleh Bung Hatta jauh sebelum 1945. Demikian daerah atau otonomi. ${ }^{16}$ Untuk memahami pula konsep-konsep mengenai pemerintahan dengan tepat, sampai sejauh manakah

Tabel

\section{Perubahan Makna}

\begin{tabular}{|c|c|c|}
\hline Pemaknaan & UU No.22/1999 & UU No.32/2004 \\
\hline Desentralisasi & $\begin{array}{l}\text { Desentralisasi adalah penyerahan } \\
\text { wewenang pemerintahan oleh } \\
\text { Pemerintah kepada daerah otonom } \\
\text { dalam kerangka NKRI. }\end{array}$ & $\begin{array}{l}\text { Desentralisasi sebagai penyerahan } \\
\text { wewenang pemerintahan oleh } \\
\text { Pemerintah kepada Daerah Otonom unluk } \\
\text { mengatur dan mengurus urusan } \\
\text { Demerintahan dalam sistem NKRI. }\end{array}$ \\
\hline Olonomi Daerah & $\begin{array}{l}\text { Otonomi Daerah adalah } \\
\text { kewenangan daerah otonom untuk } \\
\text { mengatur dan mengurus } \\
\text { kepentingan masyarakat setempat } \\
\text { menurut prakarsa sendiri } \\
\text { berdasarkan aspirasi masyarakat } \\
\text { sesual dengan peraturan } \\
\text { nerundano-undanoan. }\end{array}$ & $\begin{array}{l}\text { Otonomi Daerah dirumuskan hak, } \\
\text { wewenang dan kewajiban daerah } \\
\text { otonom untuk mengatur dan mengurus } \\
\text {.urusan pemerintahan dan kepentingan } \\
\text { masyarakat setempat sesuai dengan } \\
\text { peraturan perundang-undangan. }\end{array}$ \\
\hline $\begin{array}{l}\text { Pemerintahan } \\
\text { Daerah }\end{array}$ & $\begin{array}{l}\text { perundang-undangan. } \\
\text { Pemerintahan daerah adalah } \\
\text { penyelenggaraan pemerintahan } \\
\text { daerah otonom oleh pemerintah } \\
\text { daerah dan DPRD menurut asas } \\
\text { desentralisasi. }\end{array}$ & $\begin{array}{l}\text { Pemerintahan daerah adalah } \\
\text { penyelenggaraan urusan pemerintah } \\
\text { oleh pemerintah daerah dan DPRD } \\
\text { menurut asas otonomi dan tugas } \\
\text { pembantuan dengan prinsip otonomi } \\
\text { seluas-luasnya dalam sistem dan prinsip } \\
\text { NKRIsebagaimana dimaksud dalam UUD } \\
\text { Ri Tahun } 1945 \text {. }\end{array}$ \\
\hline Pemerintah Daerah & $\begin{array}{l}\text { Kepala daerah beserta perangkat } \\
\text { daerah otonom yang lain sebagai } \\
\text { badan eksekutif daerah. }\end{array}$ & $\begin{array}{l}\text { Pemerintah daerah adalah Gubernur, } \\
\text { Bupatl atau Wallkota dan perangkat } \\
\text { daerah sebagai unsur penyelenggara } \\
\text { pemerintahan daerah. }\end{array}$ \\
\hline PRD & $\begin{array}{l}\text { Dewan Perwakllan, Alakyat Daerah, } \\
\text { selanjutnya disebut DPRD adalah } \\
\text { Badan Legislatif Daerah. }\end{array}$ & $\begin{array}{l}\text { Dewan Perwakilan Rakyat Daerah, } \\
\text { selanjutnya disebut DPRD, adalah } \\
\text { lembaga perwakilan rakyat daerah } \\
\text { sebagai unsur penyelenggara } \\
\text { pemerintahan daerah. }\end{array}$ \\
\hline
\end{tabular}

konsep atau gagasan tersebut dituangkan dalam UUD 1945 diperlukan satu pengkajian yang khusus. Khusus mengenai Pasal 18 UUD 1945 perlu dikaji sejarah perumusannya. Dengan demikian dapat diketahui konsep, gagasan dan keinginan pembentuk UUD 1945 mengenai bentuk susunan pemerintahan daerah setelah merdeka.

${ }^{16}$ Lihat antara lain, Moh Hatta, Krisis Dunia dan Nasib Rakyat Indonesia, dalam kumpulan Karangan (1), (Bulan Bintang, Jakarta, 1978), hlm. 181 dst. 


\section{Format Konstitusionalisme}

Kita harus berpikir ulang dan menata ulang secara paradigmatik. Paradigmatik filosofis, kebijakan politis, dan peraturan perundang-undangan mengenai sistem pemerintahan dan pemerintahan daerah khususnya, adalah tiga dimensi yang bertalian erat satu sama lain, antara ketiganya ini sudah semenjak tahun 1945 susul-menyusul adanya, dalam rangka mencari satu format atau model pemerintahan dan otonomi daerah yang sesuai dengan tuntutan perkembangan politik di Indonesia, baik dalam skala lokal, nasional, regional maupun global.

Silih berganti UUD, begitu pula induk policy (misalnya GBHN), disusul peraturan penundangundangan mengenai pemerintahan dan otonomi daerah, toh sampai hari ini belum juga ditemukan satu format yang dinilai mantap dan menjanjikan bagi bangsa ini, terlebih-lebih bagi masyarakat di daerah. Justru gerakan disintegrasi dan separatisme yang bermunculan di manamana. ${ }^{17}$ Semuanya ini sebaiknya kita pulangkan kepada pernyataan pokok yakni apa latar belakang semua itu? Di mana letak akar permasalahannya? Di UUD-kah, di GBHN-kah atau di UU dan Iain-lainya? Atau di dalam niat dan tekad serte mental dan perilaku penguasanya, di Pusat atau di DaerahDaerah? Atau di semuanya?

Setelah melihat kemball jauh ke belakang berdasarkan pengalaman dan pengamatan di lingkungan pemerintahan itu, lalu menganalisa dari segi-segi teoritis konsepsional maupun praktis-operasional, akhirnya saya berpendapat dan berkeyakinan, bahwa di setiap mata-rantai itu masih perlu dibenahi kembali.

Dalam situasi yang demikian, maka UUDlah sebagai Konsep Dasar Sistem Nasional, yang akan menjadi sumber paradigma dasar yang ideal, untuk membuahi semua masalah pemerintahan, termasuk Pemerintahan dan

${ }^{17}$ Lihat Bagir Manan dalam Menyongsong Fajar Otonomi Daerah, (Penerbit Pusat Studi Hukum Fakultas Hukum Ull, Yogyakarta, 200), $1 \mathrm{hlm}$. 28. dst. Di balik itu semua, ada satu dasar sentralisasi yang tidak pemah diungkap secara terbuka yaitu purbasangka terhadap daerah. Pusat beranggapan, desentralisasl, apalagi dalam bentuk otonomi, berpotensi memecahnegara kesatuan. Daerah-daerah dengan kemandirian otonomi dapatmendorong proses memisahkan diri darinegara kesatuan. Hal ini dibuktikan dengan berbagai pergolakan yang terjadi di daerah. Premis ini, baikempirikmaupun teoritik kurang dapat dipestanggungjawabkan. Pergolakan daerah yang pernah terjadi atau sedang terjadi, bukan karena menguatnya otonomi, melainkan justru karena sentralisasi. Daerah Justru menuntut otonomi dan pergendoran sentralisast. Dengan perkataan lain, tidakmungkin pergolakan daerah terjadi akibat otonomi, karena otonomi itu sendiri belum pernah dilaksanakan. Dengan demikian, kalaupun ada atau pernah ada ancaman disintegrasi, bukanlah karena politik desentralisasi atau olonomi, melainkan sebaliknya karena politik sentralisasi. Lihat pula Ichlasul Amal, Regionai dan Central Govemment in Indonesian Poltitics, West Sumatra and South Sulawesi 1949-1979, Gadjah Mada University Press, Yogyakarta, 1992. Baca Forum Untuk Reformasi Demokralis, Penilaian Demokratisasidi indonesia, Internasional IDEA, Stokholm, Sweden, 2000, hlm. 15. Dari hasil suatu penilitian sempai pada suatu kesimpulan bahwa apa yang terjadi dI Aceh adalah "pemberontakan kaum republiken" jauh dari hasrat untuk memisahkan diri. Demikjan pula dengan gerakan PARI dan Permesta yang melanda sejumlah daerah kunci Indonesia, dirumuskan sebagai "pemberontakan setengah hati" yang lebih dimaksudkan untuk mengekspresikan ketidakpuasan ekonomi dan politik daerah yang menilai kebijakan Jakarta sangat tidak adil bagi mereka ketimbang sebuah gerakan politik untukmemisahkan diri. 
Sudi Fahmi. Upaya Menemukan Kesimbangan Hubungan...

Otonomi Daerah. Bangsa ini sedang mencaricari dan berusaha menemukan satu format konstitusionalisme yang baru bagi dirinya, untuk kepentingan penataan ulang sistem manajemen kehidupan bangsa ini di semua bidang politik ekonomi, sosial budaya dan Hankam, termasuk mengenai Pemerintahan dan Otonomi Daerah.

Konstitusionalisme yang dimaksud bukan konstitusi dalam makna rumus UUD an sich, tetapi ialah isme, ism, pandangan, pemahaman, serta ide atau doktrin untuk mendapatkan satu rumusan bentuk dan pola baru mengenai manajemen kehidupan bangsa ini dengan semua sub-sistemnya, dan ingin ditata kembali menurut paradigma yang jelas, baik paradigma di tataran filosofis, politis dan yuridis.

Hillaire Bamett mengatakan: "Constitutionalism is the doctrine which govems the legitimacy of government action. By constitutionalism is meant-in relation to constifutions written and unwritten conformity with the broad philosophical values whiten a state. ${ }^{18}$

Dalam negara kesatuan, sangat mudah muncul isu kepentingan nasional yang dipertentangkan dengan kepentingan daerah. Dalam konteks ini, Pemerintahan Pusat adalah pembela utama kepentingan nasional. Pemerintahan Pusat bertanggungjawab terhadap pelaksanaan tugas-tugas pemerintahan dan pembangunan pada tingkat nasional. Sebelum semuanya itu dimulai, harus lebih dulu diredakan gonjang-ganjing politik dan kekuasaan yang lagi berkobar secara sentral di tanah air ini. Baru kemudian duduk bersama dengan pikiran yang jernih dan idea-futuristik, untuk memikirkan format konstitusionalisme yang dipandang pas dan cocok untuk masa depan ini.

Di sinilah letak sumber kekesalan dan kegeraman masyarakat terhadap perilaku para aktor politik di tanah air ini, walaupun masih muncul keraguan apakah memang semuanya itu adalah sekedar politis atau telah berkualitas sampai ke strata negarawan (statesmen, staatsmannen), yang mampu memikirkan dan merancang hari depan bangsa dan negara ini hingga jauh ke depan (futuristik view).

Bagi Pemerintahan Pusat, sumbersumber kekayaan yang ada di daerah-daerah adalah bagian yang amat penting bagi penghasilan nasional, karena pertambahan, industri, pertanian, kehutanan dan berbagai bentuk badan usaha di daerah. Menurut kacamata Pemerintahan Pusat sumber kekayaan yang berasal dari suatu daerah adalah milik nasional yang dihasilkan oleh suatu Daerah tidak bisa hanya digunakan untuk kepentingan daerah bersangkutan. Asas pemerintahan merupakan salah satu pedoman kerja Pemerintahan Pusat sehingga sumber kekayaan yang ada di daerah tertentu dibagikan pula ke daerah-daerah lain. Akibat, kekayaan suatu daerah tidak dapat dinikmati sendirian oleh Daerah bersangkutan.

Sebaliknya, pinak daerah lebih menekankan pada kepentingan daerah. Dalam pandangan daerah, sumber-sumber kekayaan yang ada di daerahnya sering kali dianggap bisa dimanfaatkan untuk kepentingan daerah dan rakyat dl sana. Hal in terutama bila daerah bersangkutan masih terbelakang dan miskin. Semakin terbelakang

${ }^{18}$ Hilaire Barnett, BA.LL.M, Constitutional \& Administrative Law, (Cavendish Publishing Limited., Landon, Sydney, Fourth Edition, 2000), him. 5. 
suatu daerah, semakin besar tuntutan supaya sumber-sumber kekayaan yang ada di daerah yang bersangkutan digunakan pertama-tama untuk memenuhi kebutuhan pemerintahan dan rakyat di daerah tersebut. Jawaban yang utama, dimulai menata kembali "hubungan kekuasan, dan hubungan keuangan antara Pusat dan Daerah" secara nasional melalui undang-undang, kemudian disusu! dengan petunjuk pelaksanaan (juklak) yang diatur melalui Peraturan Pemerintah (PP). Yang menjadi pertanyaan awal, sebelum itu ialah sejauh mana konsensus naslonal dapat dicapai sebagai political will,yang akan menjadi landasan politis strategis buat menata hubungan yang dimaksud.

Setelah keluarnya UU Pemerintahan Daerah dan UU Perimbangan Keuangan antara Pusat dan Daerah apakah semua permasalahan sudah atau dapat segera diselesaikan? Ternyata tidak. Bahkan timbul masalah-masalah baru sebagai konsekuensi dari pergeseran garis kebijakan politik dan perundang-undangan itu, sedangkan di sisi lain, peraturan-peraturan untuk pelaksanaan tidak segera dilengkapi (organieke verordeningen). Terasa kerunyamen bahkan kekurangpastian hukum mengenai status, posisi dan fungsi, dalam konteks hubungan antara Pusat dan Daerah, bahkan juga terasa ada kesimpangsiuran pandangan dan penaisiran mengenai hakekat otonomi daerah dalam UU tersebut.

\section{Simpulan}

Menyoroti tarik ulur yang sangat keras antara sentralisasi dan desentralisasi dalam perjalanan sejarah di Indonesia, yang menyertai setiap pergantian pemegang kekuasaan pemerintahan negeri ini sejak berdiri sampai dengan sekarang, umumnya sentralisasi kekuasaan berbanding lurus dengan kekuatan basis material negara. Di saat basis material negara kuat, maka kekuasaan akan terpusat di Jakarta. Di masa Soeharto kekuasaan itu bahkan diimplementasikan secara sangat uniformistik di atas kepentingan Jakarta dan supremasi kultural Jawa. Sebaliknya, di saat basis materil melemah, apalagi di saat yang sama tekanan daerah meningkat, pusat cenderung mengendurkan tarikan sentralisasinya, dan daerah akan memperoleh ruang bagi kekuasaan. Oleh karena itu, penting untuk menerapkan desentralisasi politik itu secara bersamaan dengan demokratisasi, untuk memastikan bahwa desentralisasi itu tak akan berjalan secara eksesif.

\section{Daftar Pustaka}

AF, Leemans, Changing Patterns of Local Government. The Hague, IULA, 1970.

Amal, Ichlasul, Reglonal dan Central Government in indonesian Politics, West Sumatra and South Sulawesi 1949-1979, Gadjah Mada University Press, Yogyakarta, 1992.

Asshidiqie, Jimly, Konstitusl \& Konstitusionalisme Indonesia. Mahkamah Konstitusi Republik Indonesia dan Pusat Studi HTN Universitas Indonesia Jakarta.

Bahar, Saairoedin, dkk (penyunting), Risalah Sidang BPUPKI-PPKI, Sekretariat Negara RI., Jakarta, Cet. Kedua, Edisi IV. 1998. 
Sudi Fahml. Upaya Menemukan Kesimbangan Hubungan...

Bamett, Hilaire, BA.LL.M, Constitutional \& Administrative Law, Cavendish Publishing Limited., Landon, Sydney, Fourth Edition, 2000.

Burger, (et,al), Schets van nederlandse gemeenterecht, 3d druk, Samson, 1983.

Cheema, G. Shabbir and Dennis A. Rondinelli, Implementation Decentralization Programmes in Asla, Local Capacity of Rural Development, UNRCD, Nagoya, 1983.

Elzinga, D.J, De Democratlshe Rechtstaat Als Ontwikkeling Perspektif, dalam. Schelma (ed), De Rechtsstaat Herdacht, W.E.J. Tjeenk Willink, Zwolle, 1989.

Forum Untuk Reformasi Demokratis, Penilaian Demokratisasi di indonesla, Internasional IDEA, Stokholm, Sweden, 2000.

Hatta, Moh, Krisis Dunia dan Nasib Rakyat Indonesia, dalam Kumpulan Karangan (1), Bulan Bintang, Jakarta, 1978.

Hoessein, Bhenyamin, Pembagian Kewenangan Antara Pusat Dan Daerah, Makalah, Pusat Pengembangan Otonomi Daerah Fakultas Hukum Unibraw, Malang, 2001.

Hutchrof, Paul D., Centralization and Decentrallzation in Adminlstration and Politics: Assessing Territorial Dimensions of Authority and Power", in Government: International Journal of Policy and Administration, Vol. 14, No.1, January 2001.
Iglesias, Gabriel U., Implementation, The Problem of Achleving Results, Erofa, Manila, 1976.

Lay, Cornelis, Desentralisasi dan Otonom! Daerah: Antara Teorl dan Praktik, dalam Buku Palit, Dance. I, et.al. (Ed.), Dinamika Nasionalisme Indonesia. Yayasan Bina Darma, Salatiga, 1999.

Manan, Bagir, Perjalanan Historis Pasal 18 UUD 1945 (Perumusan dan Undang-Undang Pelaksanaannya). UNSIKA, Karawang, Tahun 1992. Menyongsong Fajar Otonomi Daerah, Penerbit Pusat Studi Hukum (PSH) Fakultas Hukum UIl, Yogyakarta, 2001.

Hubungan Antara Pusat dan Daerah Berdasarkan Asas Desentralisasi Menurut UUD 1945, Disertasi, Universitas Padjajaran, Bandung, 1990.

P., Mawhood, (Ed.) Local Government in the This World, Chichester, John Wiley and Sons, 1983.

Praktino, "Desentrallast Pilihan Yang Tidak Pernah Final", dalam Jim Schiller (edt)'. Jalan Terjal Reformasi Lokal, Program Pascasarjana Politik Lokal dan Otonomi Daerah' UGM, 2003.

Rasyid, M. Ryaas, Pilkada 2005. Terobosan Otonomi atau Kekalutan Konsep, Makalah Seminar Nasional, Keluarga Mahasiswa Administrasi Negara Universitas Gadjah Mada, 19 Maret 2005.

Situmurang, Sodjuangon, Model Pembagjan 
Urusan Pemerintahan Antara UU Nomor 22 Tahun 1999 tentang Pemerintah, Provinsi dan Kabupaten' Pemerintahan Daerah.

Kota, Disertasi, Pascasarjana UI, Jakarta, 2002

Syatrudin, Ateng, Pasang Surut Otonoml Daerah, Orasi Diesnatalis Unpar, Bandung, 1983.

Van Der Pot, C.W.(et.a)., Handboek Van Nederlandse Staatsrecht, 11d druk, W.E.J. Tjeenk Willink-Zwolle, 1983.

UU Nomor 32 Tahun 2004 tentang Pemerintahan Daerah.

UU Nomor 33 Tahun 2004 tentang Perimbangan Keuangan antara Pusat dan Daerah.

Kompas, 5 Februari 2002.

Kedaulatan Rakyat, 22 November 2004.

Kompas, 23 Maret 2005. 